\title{
ANTIBIOTIC RESISTANCE THREATS IN PATIENTS WITH INDWELLING URINARY CATHETERS: BACTERIAL SPECTRUM, INFECTION RATES AND THE EMERGENCE OF MULTIDRUG RESISTANT AND EXTENSIVELY DRUG RESISTANT STRAINS
}

\author{
Milan B. Potić1,2, Aleksandar Skakić1,2, Miodrag Djordjević1,3
}

\begin{abstract}
The extent of antimicrobial resistance has become a global threat and according to the World Health Organization latest reports on this issue, $21^{\text {st }}$ century could mark the end of the antibiotic era. Catheter-associated urinary tract infections are the leading cause of healthcareassociated bacteremia and a major source of resistant gram-negative organisms. This paper focuses on antibacterial resistance of bacterial species isolated from the urine samples of bacteriuric patients. In this study we examined urine cultures of patients with indwelling urethral catheters hospitalized for operative treatment who are at a higher risk for the emergency due to difficult to eradicate pathogens. We assessed underlying primary health conditions, comorbidities and infection risk factors in an attempt to relate them with rates of resistance. The results of susceptibility testing among positive urine isolates revealed high rates of resistance to $\beta$-lactamase inhibitors, third-generation cephalosporins, fluoroquinolones and trimethoprim-sulfamethoxazole alongside with combined resistance to third-generation cephalosporins, fluoroquinolones and aminoglycosides. Multi-drug resistant strains were isolated regardless of clinically apparent symptoms and signs of the infection with catheterization duration being the dominant factor in comparison to the severity of primary disease and comorbidities. Administration of empirical therapy failed to address resistance patterns of detected pathogens. Catheterization due to strictly defined indications, reduction of catheter presence duration and choice of therapeutic agent in accordance with susceptibility testing are currently best available strategies both for prevention and therapy.
\end{abstract}

Acta Medica Medianae 2020;59(3):90-97.

Key words: urinary tract infection, indwelling urethral catheter, health-care acquired infection, multi-drug resistance, extended drug resistance

${ }^{1}$ University of Niš, Faculty of Medicine, Niš, Serbia

${ }^{2}$ Clinical Center Niš, Clinic of Urology, Niš, Serbia

${ }^{3}$ Clinical Center Niš, Clinic of Surgery, Niš, Serbia

Contact: Milan Potić

48 Dr Zoran Djindjić Blvd., 18000 Niš, Serbia

E-mail: milan.potic@medfak.ni.ac.rs

\section{Introduction}

Hospital-acquired urinary tract infection is one of the most common healthcare-acquired infections and $70 \%$ to $80 \%$ of these infections are attributable to the use of an indwelling urinary catheter (1). Duration of catheterization is the most important determinant of bacteriuria. The term catheter-associated urinary tract infection (CA-UTI) refers to UTIs occurring in a person whose urinary tract is currently catheterized or has been catheterized within the 90 past 48 hours. A single insertion of a catheter into the urinary bladder in ambulatory patients results in urinary infection in $1-2 \%$ of cases $(2,3)$.

Indwelling urinary catheters facilitate colonization with uropathogens by providing a surface for the attachment of host cell binding receptors recognized by bacterial adhesions (4). The most common infecting organism is Escherichia coli, Enterococcus spp., coagulase-negative Staphylococcus, Pseudomonas aeruginosa and other non-fermenters (5). Bacterial resistance has major implications for urological practice, particularly in relation to catheterassociated UTIs and infection complications following prostate biopsy or urological surgery (6). Catheterassociated urinary tract infection has been associated with increased morbidity, mortality, hospital costs and length of hospital stay (7).

\section{Patients and methods}

A prospective study was performed during a one-year period in the Urology Clinic, Clinical Center Niš. A total of 217 patients admitted for operative 
treatment were studied. The inclusion criteria were restricted to patients with indwelling urinary catheter present for more than two days prior to admission. The patients undergoing catheterization for diagnostics or complicated urinary drainage procedures (nephrostomy, urinary stents) were excluded. Duration of catheter presence was considered to be shortterm catheterization (STC) if they were in situ for up to 29 days or less and long-term catheterization (LTC) when they were in situ for 30 or more days.

The analysis was performed on the following collected data: urine samples taken on admission, on the $5^{\text {th }}$ day of hospitalization, on the $5^{\text {th }}$ postoperative day and after removal of the catheter. All urine samples were sent to microbiology laboratory and assessed for the presence of pathogens and their antimicrobial susceptibility in accordance to the European Committee on Antimicrobial Susceptibility Testing standards. All positive urine cultures were cross-linked with antibiotics from different classes to obtain a resistance percentage of isolated microorganisms. Multidrug-resistant (MDR) strains were defined as non-susceptibility to at least one agent in three or more antimicrobial categories and extensively drug-resistant (XDR) as non-susceptibility to at least one agent in all but two or fewer antimicrobial categories. In order to assess general resistance multiple antibiotic resistance (MAR), indexes were calculated by dividing the number of antibiotics isolate is resistant to with a number of antibiotics it is tested against. Empirical therapy was considered adequate if isolates were tested sensitive to administered antibiotics.

Infections were classified as present on admission (POA) and hospital-acquired urinary tract infection (HAUTI). Hospital-acquired urinary tract infection is defined as a microbiologically confirmed or symptomatic UTI with the date of onset. The day one of infection window period (IWP) was the day of admission to the urology clinic regardless of patient transfer from intensive care unit or another ward. Catheter-associated urinary tract infections were defined as positive urine culture with at least one bacterial species isolated at quantitative counts $\geq 10^{5} \mathrm{CFU} / \mathrm{ml}$ in patient with indwelling urinary catheter for $>2$ days prior to infection or symptoms and signs suggestive of UTI (fever $>38{ }^{\circ} \mathrm{C}$, lower abdominal/flank pain or leukocytosis with no other recognized cause). Catheter-associated asymptomatic bacteriuria ( $C A-A B U$ ) was defined as at least one bacterial species isolated from urine culture at quantitative counts $<10^{5} \mathrm{CFU} / \mathrm{ml}$ in a patient with an indwelling urinary catheter for $>2$ days without symptoms and signs of UTI.

Urinary tract infection risk factors considered were: an indwelling urinary catheter for $>2$ days, extended duration of catheterization, previous history of UTI, urinary tract obstruction or reflux, urinary stones, antibiotics or corticosteroids treatment within previous three months and hospitalization within previous six months. These factors were not analyzed separately and were expressed as a total number of factors simultaneously present (minimum one; +1 for LTC). The underlying primary disease was classified with McCabe and Jackson score. Comorbidity severity level was assessed by Carlson Comorbidity Index (CCI). Additional data of interest collected were: baseline characteristics, duration of catheter presence prior to admission, indications for catheters usage, administration of antibiotics, duration of antibiotic therapy and the total length of hospital stay (LOS).

Statistics: Pearson correlation test, KruskalWallis analysis of variance (ANOVA) followed by Man-Whitney $U$ test have been used. SPSS 11 (Chicago, IL, USA). P-values $<0.05$ were considered to be statistically significant.

\section{Results}

Out of 217 patients included in the study, there were 154 (71\%) male patients and 63 (29\%) female patients with a median age of 65 years (range 21-84). Long-term catheterization was present in $58(27 \%)$ patients (median catheter time in situ 63.5 days, $\min 30, \max 459$ ) and short-term catheterization in 159 (median 6 days, min 2, max 29). In 126 patients (58\%) indication for catheterization was surgery, acute obstruction in 80 (37\%) and hematuria or trauma in remaining $11(5 \%)$ patients. The open-drainage system was present in 36 (16\%) patients. The most common type (94\%) of urinary catheter used was Foley silicone-coated catheter.

Sixty-eight (31\%) urine cultures taken on admission were positive for at least one bacterial species. Among these patients six had a fever on admission with accompanying symptoms and signs suggestive of UTI and they were identified as CAUTI. Of all patients with POA infection, change of causative pathogen occurred in 19 (30\%) cases and HAUTI was considered. Of 149 urine samples sterile on admission, 97 (65\%) were positive for bacterial presence on the fifth hospital day and stratified as follows: $16(16.6 \%)$ patients had symptoms and were classified as CA-UTI, 25 (25.7\%) patients were asymptomatic with bacterial growth $<10^{5} \mathrm{CFU} / \mathrm{mL}$ and were classified as CA-ABU and 56 (57.7\%) patients were asymptomatic with bacterial growth > $10^{5} \mathrm{CFU} / \mathrm{mL}$ and classified as HAUTI. In patients with HAUTI, change of pathogen occurred in 26 (39\%) cases on the next sampling. In four of HAUTI patients, infection deteriorated to the level of sepsis. Ratios of organisms isolated from urine samples are presented in Figure 1. Most frequently isolated species present on admission were E. Coli (49\%), Pseudomonas spp. (16.5\%) and Proteus mirabilis (14\%). Among hospital-acquired pathogens most common were E. Coli (40\%), E. Faecalis (16\%), Pseudomonas spp. and Klebsiella spp. (12.5\% both). The most common changes of isolated bacteria were in a favor of Klebsiella ( $p<0.001$ ) with consequent reduction of $E$. Coli $(p<0.05)$. The spectrum of causative organisms was virtually identical in LTC and STC patients (higher but not significant presence of $P$. Mirabilis was found in LTC).

Cumulative percentages of resistance toward antibacterial category representatives and additional 
data are summarized in Table 1 . In $74 \%$ of cases antibacterial therapy was empirical with the adequacy of $19 \%$. Twenty-six percent of patients were treated in accordance with antibiogram and in one case treatment was considered non-adequate. Mean duration of antibiotics treatment was 6.5 days
$(\mathrm{SD}=4.1, \max 17)$. In a total of 351 susceptibility tests performed resistance rates from $68.7 \%$ to $100 \%$ were found to second-generation cephalosporins, fluoroquinolones and trimethoprim-sulfamethoxazole (TMP-SMX).

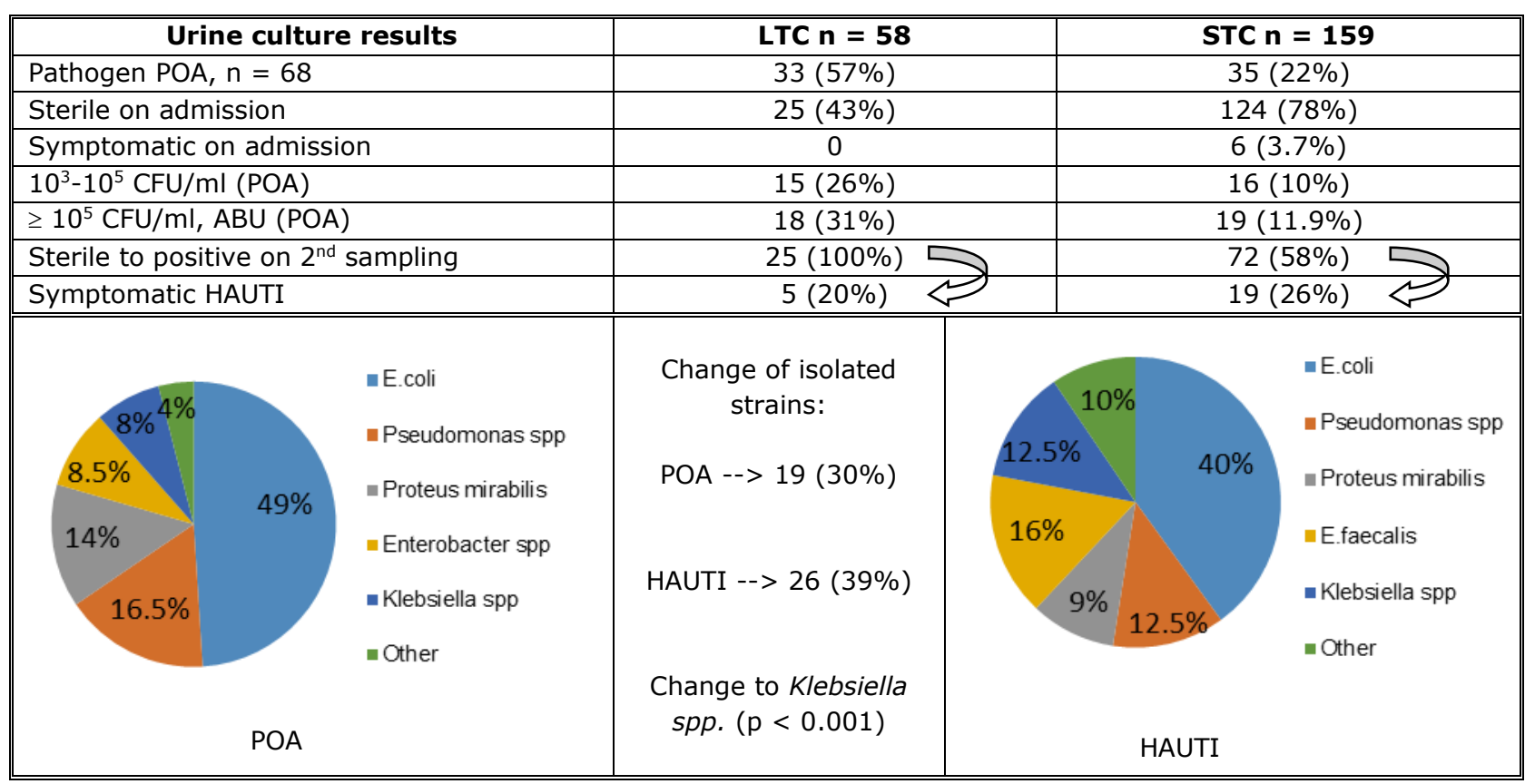

Abbreviations: LTC- long-term catheterization; STC- short-term catheterization; POA- present on admission; ABU-asymptomatic bacteriuria; HAUTI- hospital-acquired urinary tract infection.

Figure 1. Urine culture results and bacterial spectrum of positive isolates

Table 1. Isolated pathogen resistance to commonly used antimicrobials

\begin{tabular}{|c|c|c|c|c|c|}
\hline \multirow[b]{2}{*}{ Antibacterial agent } & \multicolumn{5}{|c|}{ Antibiotic resistance percentages (\%) } \\
\hline & $\begin{array}{c}\text { E. Coli } \\
\mathrm{n}=152\end{array}$ & $\begin{array}{l}\text { Pseudomonas } \\
\text { spp. } \mathrm{n}=48\end{array}$ & $\begin{array}{c}\text { P. Mirabilis } \\
\mathrm{n}=37\end{array}$ & $\begin{array}{c}\text { Klebsiella spp. } \\
\mathrm{n}=42\end{array}$ & $\begin{array}{c}\text { Enterobacter } \\
\text { spp. } \mathrm{n}=22\end{array}$ \\
\hline Amoxicillin-clavulanate & 38.6 & 73.2 & 35.7 & 70.8 & 84.1 \\
\hline Piperacillin-tazobactam & 23.5 & 43.5 & 0.0 & 6.3 & 9.1 \\
\hline Cefuroxime & 47.5 & 74.1 & 42.9 & 82.3 & 83.8 \\
\hline Ceftriaxone & 36.7 & 65.3 & 51 & 59.5 & 50.9 \\
\hline Cefotaxime & 35.3 & 51 & 26.7 & 55.2 & 56.7 \\
\hline Ceftazidime & 33.4 & 39.8 & 49 & 57.8 & 66.7 \\
\hline Cefepime & 14.3 & 24.5 & 0.0 & 32.2 & 33.6 \\
\hline Ciprofloxacin & 68.7 & 95.7 & 72.5 & 88.9 & 82.4 \\
\hline Gentamicin & 45.7 & 61.3 & 56.3 & 89.3 & 76.5 \\
\hline Amikacin & 26.6 & 38.3 & 25 & 57.1 & 52.9 \\
\hline Trimethoprim/sulfamethoxazole & 95.3 & 100 & 96.3 & 100 & 93.8 \\
\hline \multicolumn{6}{|l|}{ Type of resistance } \\
\hline MDR & $21(13.8 \%)$ & $9(18.7 \%)$ & $5(13 \%)$ & $11(26 \%)$ & $6(27 \%)$ \\
\hline XDR & $7(4 \%)$ & $14(29.1 \%)$ & no & $7(16 \%)$ & $4(18 \%)$ \\
\hline POA/HAUTI ratio & 0.8 & 0.91 & 0.98 & 0.4 & 3.0 \\
\hline
\end{tabular}

Abbreviations: MDR-Multidrug-resistant. XDR-Extensively drug-resistant. POA-Present on admission.

HAUTI-Hospital-acquired urinary tract infection. MAR-Multiple Antibiotic Resistance index. 
Sixty percent of POA pathogens and $87.2 \%$ of HAUTI were resistant to empirically administered fluoroquinolones, with a higher resistance rate of hospital strains $(p<0.001)$. Resistance rates from $33 \%-66.7 \%$ were recorded to cephalosporins of the third generation along with resistance to cefepime over 30\% among Klebsiella species and Enterobacter species. In regard to cephalosporins, isolated causative pathogens shared similar rates of resistance to the particular antibacterial drug, from moderate $70.3 \%$ among Pseudomonas and Proteus to $97.6 \%$ for E. Coli and Klebsiella spp. None of the isolates were resistant to carbapenem group (imipenem, meropenem). Highest numbers of MDR strains were found among Klebsiella (26\%) and Enterobacter (27\%) with Pseudomonas spp. being the most prominent pool of XDR pathogens $(29.1 \%)$. $E$. Faecalis resistance rates are not given in the Table 1 due to data consistency and are presented in the text. Isolated strains of $E$. Faecalis $(n=50)$ showed the highest resistance to TMP-SMX (98\%), ciprofloxacin $(90 \%)$ and doxycycline $(68.4 \%)$ along with susceptibility to carbapenems $(100 \%)$ and aminoglycosides (amikacin $100 \%$, gentamicin $85 \%$ ).

There was one single vancomycin-resistant isolate of $E$. Faecalis.

Mean MAR index of POA pathogens was 0.62 $(S D=0.25)$ and in HAUTI mean MAR index was $0.65(S D=0.18)$. In the cases of same species isolated on the next successive sampling, MAR index increased from average 0.42 to 0.57 . With the occurrence of pathogen species exchange, mean MAR indexes changed from 0.52 to 0.61 respectively $(p<0.05)$. The most frequently isolated pathogen $E$. Coli change of resistance rates in accordance with the time of isolation is presented in Figure 2.

Based on the duration of catheterization, MAR values were as follows: in LTC mean MAR value was $0.63(\mathrm{SD}=0.22)$ and in STC mean MAR value was $0.54(S D=0.26)$ with the signifficant difference between groups $p<0.05$. In respect to primary disease evaluated by McCabe and Jackson score, patients with LTC had a nonfatal condition in $60 \%$ of cases, fatal within 5 years in $30 \%$ and lifethreatening within 6 months in $10 \%$ of cases. Patients with STC had a nonfatal condition in $52 \%$ of cases, fatal within 5 years in $41 \%$ and life-threatening within 6 months in $7 \%$ of cases. Significant correlation between severity of primary disease and bacterial resistance was found $(p<0.05)$. Mean Carlson index in LTC was $3.43(\mathrm{SD}=2.45)$ and in STC mean Carlson index was 3.48 (SD = 2.42). The relation of pathogen resistance and comorbidity was not significant. A weak positive correlation existed between a number of predisposing factors and occurrence of infection $p=0.06$. Regarding length of hospital stay (LOS) in LTC patients, mean value was 26.8 days $(S D=20.5)$ and in STC was 18.9 days $(S D=9.4)$. The correlation between resistance rates and LOS in both groups of patients was not significant.

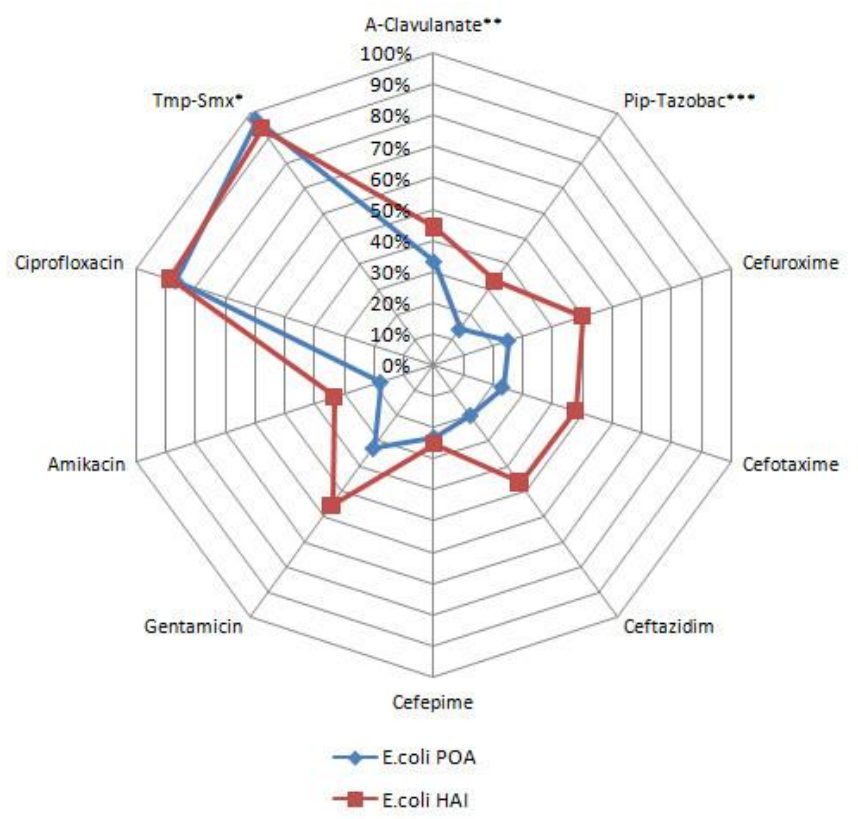

Abbreviations: Tmp-Smx*: Trimethoprim-sulfamethoxazole, A-clavulanate**: Amoxicilin-clavulanate, Pip-Tazobac***: Piperacillin-Tazobactam

Figure 2. Resistance pattern between present on admission and hospital-acquired strains of $E$. Coli 


\section{Discussion}

The urine of patients with indwelling catheters is a source of extended-spectrum beta-lactamase (ESBL) and carbapenem-resistant (CRE) Enterobacteriaceae in both acute and long-term facilities $(8,9)$. The species isolated in our study demonstrated a high level of resistance to $\beta$-lactamase inhibitors, third-generation cephalosporins and combined resistance to cephalosporins, fluoroquinolones, and aminoglycosides. None of these showed resistance to the carbapenem group of antibiotics. European Centre for Disease Prevention and Control (ECDC) report on $A B R$ in 30 countries of EU/EEA warned that the resistance to carbapenems significantly increased from a population-weighted of $6.2 \%$ in 2012 to $8.1 \%$ in 2015. Resistance to carbapenems was frequently reported in $K$. Pneumoniae invasive isolates from countries in Southern and South-Eastern Europe than other parts of Europe. The vast majority of the resistant isolates had additional resistance to fluoroquinolones, third-generation cephalosporins and aminoglycosides (10). The isolated pathogens we had are showing a similar pattern of combined resistance to that described in ECDC report, suggesting the possibility of ABR expansion to carbapenems. Moreover, observed high correlations of susceptibility/resistance rates among the isolates of different species to particular antibiotic raises the question of the possible cause of this finding.Indwelling catheters with open-drainage systems result in bacteriuria in almost $100 \%$ of cases within 3-4 days (3). More than a half of urine cultures of patients with LTC in our study were positive on admission and all of previously sterile become bacteriuric on the day 5 of hospital stay. A large percent of urine cultures obtained from STC patients $(58 \%)$ became positive during hospitalization. In both groups, symptomatic cases appear with delayed response to therapy and serious complications including sepsis. Part of these findings could be attributed to the presence of open-drainage systems, underlying primary disease and comorbidities potential to alter host defense mechanisms. Another determinant in our case is the unavailability of catheters with additional protective features.

Most hospital-acquired UTIs are associated with catheterization and most occur in patients without signs or symptoms referable to the urinary tract $(11,12)$. Infections originate from one species of bacteria and as the duration of catheterization lengthens, more bacterial species are usually detected (these tend to be gram-negative bacteria such as Proteus mirabilis and Pseudomonas aeruginosa) (13).

The risk of infection reduced from $97 \%$ with an open drainage system to $8-15 \%$ when a sterile closed system was employed. The risk of using antibiotics as a form of prophylaxis is that it may lead to an increase in resistance which, in turn, may reduce the available treatments for patients with clinical infections in the future (14).

Among hospitalized patients with an indwelling catheter $60-80 \%$ receive antimicrobials usually for indications other than urinary tract infection (15).
This intense antimicrobial exposure promotes antimicrobial-resistence of pathogens frequently isolated from the urine of catheterized individuals. Bacteria colonizing the drainage bags of catheterized patients have been reported to be a source for outbreaks of resistant organisms in acute care facilities (15).

According to the ECDC reports on high ABR rates in South Eastern Europe, we examined the results of the past and recent studies in geographically close regions. A significant high combined resistance was seen in Bosnian surveillance study of urinary intrahospital infections (16). The setting of this study was confined to the Clinic of Obstetrics and Gynecology and differ both in the choice of the target population and some definitions of standards. Nevertheless, the spectrum of pathogens and high percentages of their resistance to multiple antimicrobial groups alongside with susceptibility to carbapenems and fourth-generation cephalosporines were similar to our findings. A large study of communityacquired UTIs in South Croatia back in 2003 concluded that Enterobacteriaceae had become less susceptible to commonly used antibiotics and that uropathogens were showing a slow but steady increase in resistance (17). The summary of latest reports by ECDC with Croatia as EU member included, confirmed the persistence of aforementioned trends (18).

In a more recent study at the University Clinical Center of the Republic Srpska, the ABR and MDR isolates obtained from different wards were compared. They found that highest percent of MDR isolates from urine samples were comprised of Pseudomonas spp. and Acinetobacter spp. The leading sources of infections were intensive care units and surgical wards (19). None of the Acinetobacter spp. was isolated from samples we obtained at urology ward only.

Microbiological laboratory analysis of the isolates we collected demonstrated highest ABR among hospital-acquired species with Klebsiella and Proteus being a leading source of MDR strains. Once again duration of catheterization proved to be a decisive factor in the appearance of infection and pathogens harder to eradicate in patients with otherwise similar underlying pathology, comorbidities and risk factors.

The resistance demonstrated to Ciprofloxacin and TMP/SMX resulted in near zero efficiency of these antibiotics among our patients. Furthermore, levels of resistance to amoxicillin-clavulanate, thirdgeneration cephalosporins and gentamicin (ranges from $35 \%$ to even $84 \%$ ) were high above proposed limits for therapeutic efficiency. Infectious Diseases Society of America Guidelines on the treatment of uncomplicated UTIs recommended that the resistance percentage of causative micro-organisms must be $<20 \%$ to consider an agent suitable for empirical treatment of a lower UTI and must be $<10 \%$ for the treatment of an upper UTI $(3,20)$. Considering the current resistance percentages of amoxicillin, amoxiclav and trimethoprim/sulfamethoxazole, it can be concluded that these agents are not suitable for the empirical treatment of pyelonephritis in a normal host and therefore also not for treatment of all complicated UTIs. The same applies to ciprofloxacin 
and other fluoroquinolones in catheterized urological patients (21). Ciprofloxacin resistance in E. Coli isolates is increasing and the use of this antimicrobial agent as empirical therapy for UTI should be reconsidered (22).

In a broader sense, the emergence of ABR strains and their resistance rates are showing a tendency to rise and expand. This is mainly attributed to incorrectly prescribed therapeutics, subtherapeutic antibiotic concentrations and lack of new antibiotics (23). The over-application of antimicrobials usually occurs in extreme cases in hospitalbased patients and is relatively controlled. The development and implementation of rapid and accurate diagnostics would alleviate this problem (24).

\section{Conclusion}

The non-standard procedure of consecutive urine analysis and susceptibility testing of bacteria found in all catheterized patients regardless of indicative symptomatology gave us the insight into antibacterial resistance profile of often omitted microbes. These bacterial strains demonstrated a high level of antibiotic resistance and combined resistance to third-generation cephalosporins, fluoroquinolones and aminoglycosides. In a management of UTI in catheterized patients, the choice of therapeutic agent should be tailored to the results of susceptibility testing of isolated pathogens since empirical therapies often fail to address the frequent presence of MDR and XDR strains. Asymptomatic bacteriuria should not be treated in catheterized patients. Duration of catheterization is the single independent factor influencing emergence of MDR and XDR strains.

\section{Acknowledgments}

This work has been supported by the Serbian Ministry of Education and Science, grant No. 175092 and grant No. III46013. 


\section{References}

1. Magill SS, Edwards JR, Bamberg W, Beldavs ZG, Dumyati G, Kainer MA et al. Multistate point-prevalence survey of healthcare-associated infections. N Engl J Med 2014;370:1198-208. [CrossRef] [PubMed]

2. Hooton TM, Bradley SF, Cardenas DD, Colgan R, Geerlings SE, Rice JC et al. Diagnosis, prevention and treatment of catheter-associated urinary tract infection in adults. 2009 international clinical practice guidelines from the Infectious Diseases Society of America. Clin Infect Dis 2010;50:625-63. [CrossRef] [PubMed]

3. G. Bonkat R, Pickard R, Bartoletti F, Bruyere SE, Geerlings F, Wagenlehner BW. Guidelines Associates: T. Cai, B. Kőves, A. Pilatz, B. Pradere, R. Veeratterapillay (Last updated: March 2017) The European Association of Urology (EAU) Guidelines on Urological Infections. "cited 2017 June" Available from: URL: https://uroweb.org/guideline/urological-infections/

4. Jacobsen SM, Stickler DJ, Mobley HL, Shirtiff ME. Complicated catheter-associated urinary tract infections due to Escherichia coli and Proteus mirabilis. Clin Microbiol Rev 2008;21:26-59. [CrossRef] [PubMed]

5. Nicolle LE. Urinary catheter-associated infections. Infect Dis Clin North Am 2012; 6:13-28.

[CrossRef] [PubMed]

6. Carolyn G, Craig AU, Rajender KA, Gretchen K, David AP. MD and the Healthcare Infection Control Practices Advisory Committee (HICPAC). Guideline for Prevention of Catheter-associated Urinary Tract Infections 2009. Available from: URL:

https://www.cdc.gov/infectioncontrol/guidelines/cauti/

7. Givens CD, Wenzel RP. Catheter-associated urinary tract infections in surgical patients: A controlled study on the excess morbidity and costs. J Urol 1980; 124(5):646-8. [CrossRef] [PubMed]

8. Brennan BM, Coyle JR, Marchaim D, Pogue JM, Boehme M, Finks J et al. Statewide surveillance of carbapenem-resistant enterobacteriaceae in Michigan. Infect Contr Hosp Epidemiol 2014;35:342-9.

[CrossRef] [PubMed]

9. Arnoldo L, Migliavacca R, Regattin L, Raglio A, Pagani $L$, Nucleo $E$ et al. Prevalence of urinary colonization by extended spectrum-beta-lactamase Enterobacteriaceae among catheterized inpatients in Italian long term care facilities. BMC Infect Dis 2013;13:124. [CrossRef] [PubMed]

10. European Centre for Disease Prevention and Control. Summary of the latest data on antibiotic resistance in the European Union. Stockholm (SE): ECDC; 2016.

11. National Clinical Guideline Centre (UK). Infection: Prevention and Control of Healthcare-Associated Infections in Primary and Community Care: Partial Update of NICE Clinical Guideline 2. London: Royal College of Physicians (UK); 2012.

12. National Nosocomial Infections Surveillance (NNIS) System Report, data summary from January 1992 through June 2004, issued October 2004. Am J Infect Control 2004;32:470-85. [CrossRef] [PubMed]

13. Stickler D, Sabbuba N. Disinfection and decontamination: Principles, applications and related issues. Taylor and Francis Ltd 2007;18:415-55.

14. Stark RP, Maki DG. Bacteriuria in the catheterized patient. What quantitative level of bacteriuria is relevant? N Engl J Med 1984;311:560-4. [CrossRef] [PubMed]

15. Lo E, Nicolle LE, Coffin SE, Gould C, Maragakis L, Meddings J et al. Strategies to prevent catheterassociated urinary tract infections in acute care hospitals 2014 update. Infect Control Hosp Epidemiol 2014;35:464-79. [CrossRef] [PubMed]

16. Čustović A, Zulčić-Nakić V, Aščerić $M$, Hadžić $S$. Surveillance of Intrahospital Infections at the Clinic for Gynaecology and Obstetrics. Bosnian Journal of Basic Medical Sciences. 2009;9(1):66-70. [CrossRef] [PubMed]

17. Zvonimir B, Andrea BE, Elmica B, Vinko Z, Vanja K, Merica $C$. Urinary tract infections in South Croatia: aetiology and antimicrobial resistance. Int J Antimicrob Ag 2003;22: 61-4. [CrossRef]

18. European Centre for Disease Prevention and Control. Annual Epidemiological Report 2016 - Healthcareassociated infections acquired in intensive care units. Stockholm (SE): ECDC; 2016.

19. Darija K, Duška J, Miroslav P. Izolati multirezistentnih bakterija u Univerzitetskom kliničkom centru Republike Srpske. Med Čas 2017;51(1):15-21.

20. Gupta K, Hooton TE, Naber KG, Wulit B, Colgan R, Miler LG et al. International Clinical Practice Guidelines for the Treatment of Acute Uncomplicated Cystitis and Pyelonephritis in Women: A 2010 Update by the Infectious Diseases Society of America and the European Society for Microbiology and Infectious Diseases. Clin Infect Dis 2011;52(5)103-20.

[CrossRef] [PubMed]

21. Wagenlehner F, Tandogdu Z, Bartoletti R, Cai T, Cek $M$, Kulchavenya $E$ et al. The Global Prevalence of Infections in Urology Study: A Long-Term, Worldwide Surveillance Study on Urological Infections. Pathog 2016;5:223-37. [CrossRef] [PubMed]

22. Fasugba O, Gardner A, Mitchell BG, Mnatzganian G. Ciprofloxacin Resistance in Community- and HospitalAcquired Escherichia Coli Urinary Tract Infections: A Systematic Review and Meta-Analysis of Observational Studies. BMC Infect Dis 2015;15:545.

[CrossRef] [PubMed]

23. Ventola CL. The Antibiotic Resistance Crisis: Part 1: Causes and Threats. Pharm and Ther 2015; 40(4): 277-83. [PubMed]

24. Michael CA, Dominey-Howes D, Labbate M. The Antimicrobial Resistance Crisis: Causes, Consequences, and Management. Front Pub Healt 2014;2:145. [CrossRef] [PubMed] 


\title{
OPASNOSTI ANTIBIOTSKE REZISTENCIJE KOD BOLESNIKA SA STALNIM URINARNIM KATETEROM: BAKTERIJSKI SPEKTAR, UČESTALOST INFEKCIJA I POJAVA MULTIREZISTENTNIH I EKSTENZIVNO REZISTENTNIH SOJEVA
}

\author{
Milan B. Potić1,2, Aleksandar Skakić1,2, Miodrag Đorđević1,3 \\ ${ }^{1}$ Univerzitet u Nišu, Medicinski fakultet, Niš, Srbija \\ ${ }^{2}$ Klinika za urologiju, Klinički centar Niš, Niš, Srbija \\ ${ }^{3}$ Klinika za hirurgiju, Klinički centar Niš, Niš, Srbija \\ Kontakt: Milan Potić \\ Bulevar dr Zorana Đinđića 48, 18000 Niš, Srbija \\ E-mail: milan.potic@medfak.ni.ac.rs
}

\begin{abstract}
Obimnost antibiotske rezistencije predstavlja globalnu opasnost i prema najnovijim izveštajima Svetske zdravstvene organizacije, 21. vek može da označi i kraj antibiotske ere. Urinarne infekcije povezane sa kateterizacijom vodeći su uzrok nozokomijalnih bakterijemija i glavni su izvor rezistentnih Gram-negativnih organizama. Ovaj rad se fokusira na antibiotsku rezistenciju bakterija izolovanih iz urina bakteriuričnih bolesnika. U ovoj studiji ispitivane su urinokulture bolesnika sa permanentnim urinarnim kateterom, hospitalizovanih zbog operativnog lečenja, kod kojih postoji povećani rizik od pojave rezistentnih patogena. Analizirani su i primarna oboljenja, komorbiditeti i faktori rizika za nastanak infekcija, u nastojanju da se dovedu u vezu sa stopama rezistencije. Testovi osetljivosti izvedeni na uzorcima pozitivnih urinokultura otkrili su visoke stope rezistencije na inhibitore beta-laktamaze, cefalosporine treće generacije, fluorohinolone i trimetoprim-sulfametoksazol, kao i kombinovanu rezistenciju na cefalosporine treće generacije, fluorohinolone i aminoglikozide. Multirezistentni sojevi izolovani su nezavisno od prisustva simptoma i znakova infekcije, pri čemu je trajanje kateterizacije dominantni faktor rizika, u poređenju sa težinom osnovne bolesti i komorbiditetima. Primenjena empirijska terapija pokazala se neadekvatnom u lečenju izolovanih patogena. Kriza antibiotske rezistencije je na vrhuncu i zahteva brz i odlučan odgovor. Kateterizacija prema strogo određenim indikacijama, smanjenje vremena trajanja kateterizacije i izbor antibiotika po antibiogramu, trenutno su najbolje strategije, kako u prevenciji tako i u terapiji.
\end{abstract}

Acta Medica Medianae 2020;59(3):90-97.

Ključne reči: urinarne infekcije, uretralni kateter, nozokomijalne infekcije, multirezistentnost, proširena rezistencija 